\title{
Everybody Loves Joe
}

Henry B. Balfanz, Northern Michigan University, USA

Gary J. Brunswick, Ph.D., Northern Michigan University, USA

\begin{abstract}
This is a case about an entrepreneur who has spent his entire life riding, fixing, and selling bicycles. While the business is a family business, there is little doubt that it revolves around the owner and his reputation as not only a smart businessman, but also as a very honest, friendly, approachable individual. The case discusses the business in detail, from the early days to the present. The owners of the business, Joe and Cheryl Russell, have seen the marketing landscape change greatly in the past thirty-five years. Making advertising decisions is not as easy as it used to be, thanks to all the new media choices. In addition to making the proper selections, the Russells also wonder if they are spending too much money on advertising and promotion. Many other bicycle dealers spend much less on promotion than the Russells do.
\end{abstract}

“I’ve never met a bike I didn't like." (Joe Russell)

Keywords: Sports Retailing; Cycling; Promotion; Advertising

\section{INTRODUCTION}

$\mathscr{J}$

oe Russell has been a fan of bicycles from the very start. Encouraged by his parents, and with the help of siblings and spouse, the business has grown from the family garage to a very large store with over 400 assembled bicycles, exercise equipment, repair shop, and much more. The reputation of Russells Cycling and Fitness has always been top notch and regarded as a place where customers can find a good bike and know they'll have the service to back it up when it is needed. Though located in a small town, Russells Cycling and Fitness draws customers from a 100-mile radius. Russell's has always been a big advertiser in the Peoria market as well, spending 7 to $10 \%$ of their yearly sales on traditional media. Sales continue to grow each year, despite the fact that Peoria has a number of good bike stores.

\section{PONDERING THE CHANGES}

As Joe Russell finished writing a comment for his company's Facebook page, his thoughts went back to the old days (the '70s), when he was just a kid working out of the family garage assembling and repairing bicycles, working with an advertising budget that consisted pretty much of "word-of-mouth" and an occasional ad in the Washington Reporter newspaper that listed only a phone number and his name.

Over the years, Joe tried many different forms of advertising. While still being a big fan of traditional advertising, such as TV and radio, he had to admit that he was quite impressed with the targeting of his potential customers that Facebook and other social media gave him. He often wonders what will replace Facebook and how will we reach our customers and potential customers in another thirty-five years?

\section{THE EARLY DAYS}

Joe started his business at the age of 18 , working out of the family garage. One of his first dates with his childhood sweetheart, and now life-long bicycle built-for-two partner, Cheryl Anderson, was spent on a Saturday night doing a parts inventory. When Joe found that Cheryl enjoyed the ins and outs of the bicycle business as much as he did, it was love at first ride. 
Though they were proud of their third oldest child, Rosalee and Everett Russell wanted their garage back. The central Illinois winters of 1977, 1978, and 1979 were especially brutal, with bitter cold and record snowfall. Every morning during the winter, family members would have to trudge out to the driveway to clean the snow off the family vehicles since young Joe had laid claim to the garage to keep his new and used AMF and Ross bicycles and tons of parts and accessories - dry in the two-car garage.

If the business is going to grow and someday move into its own facility, Joe knew he needed to expand and get his name well known in the health, fitness, and biking communities. He hired himself out to build bicycles for the local Belscot Department store and a Peoria variety store, Prospect Super Variety. He found he was able to assemble bicycles sturdier and stronger than the actual manufacturer's specifications by paying attention to detail and turning the wrench an extra ninety degrees when it was needed. This was a valuable lesson to teenage Joe Russell. Not everyone in the bicycle building business paid as much attention to detail as he did. This attention to the small things is what made the business grow.

As the 1970s came to a conclusion and with the help of his mom and dad, his sister, two brothers, and Cheryl, Joe moved Russell's Cycling and Fitness into its very first away-from-home store in 1980. The new location was right off the square in the hometown of Washington, Illinois, on a not very visible side street. With only 900 square feet, Joe had to make do with what he could afford. By this time, Joe was building quite a good reputation and, despite the non-ideal location and lack of space, people in the area knew of him and would seek out his destination location bike shop.

At this time, Joe added his first employee, Kevin Thieme. Later in the early eighties, he added Bernie Camp. Joe credits them with a lot of his success and, at the same time, they only say good things about Joe and Cheryl.

The 1980s were a time of fast growth for Russell's Cycling and Fitness as the area came out of a nearly decade long recession and a reduction of workforce by the area's biggest employer, Caterpillar Tractor Company. Caterpillar's world headquarters is in nearby Peoria, Illinois. Washington is considered a bedroom community and remains, to this day, the home of many white collar and blue collar Caterpillar employees.

During this decade as well, Joe discovered that he needed to advertise. He expanded his budget greatly. For a period of time, he engaged the services of Mary Oakley, a long time Peoria area Creative Director who was best known for her commercials for Bergners, a large Midwest department store chain. Joe credits Mary with 'putting him on the map' with her many creative ideas for radio and television commercials. Like Joe, Mary was a stickler for detail, and this fact was not lost on Joe. Thanks to her coaching, Joe became a very credible spokesperson for the business he had created in the family home.

Joe points to the year 1983 as a 'milestone' year for Russell's Cycling and Fitness. "Our sales exceeded $\$ 250,000$ that year and we felt we had finally arrived," says Russell. To create that amount of sales in such a small facility was no small feat. However, the success they experienced, despite the obstacles, made Joe and Cheryl Russell feel that nothing could stand in their way on their drive to succeed.

Word spread. The advertising had a positive impact and sales grew. Joe takes no credit for being an entrepreneurial wizard; he simply is himself and, to this day, he believes that good service and attention to detail is what will make the difference between failure and success. business.

It was becoming obvious that the 900 square feet location was simply not enough for the Russells' growing

\section{THE FAST GROWING 1990s}

It was in 1992 that Russell's Cycles became Russell's Cycling and Fitness as Joe saw the growing fitness industry to be more than just two-wheeled transportation. That year, he added treadmills, exercise bikes, stationary bikes, and more. He was excited to see a lot of interest in that very first year. According to Joe, "It always takes a 
snowfall or a spell of extremely cold weather to get people interested in indoor exercise equipment. This works well for us because when there's snow on the ground or below zero temperatures, no one is coming in to look at bicycles." Joe was able to level out the sales of the business by becoming part of the fitness craze, now keeping himself and his staff busy twelve months out of the year. At this point, the Russells decided to make a major investment in their future.

Before the days of multiplex movie theatres (the first multiplex hit the Peoria market in 1979), the local theatre was a gathering place for families, especially in the small towns where local entertainment was virtually nonexistent. So, when Joe and Cheryl Russell announced in 1994 that they were moving into the new empty Valley Forge Cinema building in the Valley Forge Shopping Center along Washington's busiest street, the local citizenry cheered the move! In order to keep a nostalgic touch, the Russells decided to leave the highly visible old movie marquee and utilize it for their new bigger and improved store. This was a masterful public relations stroke.

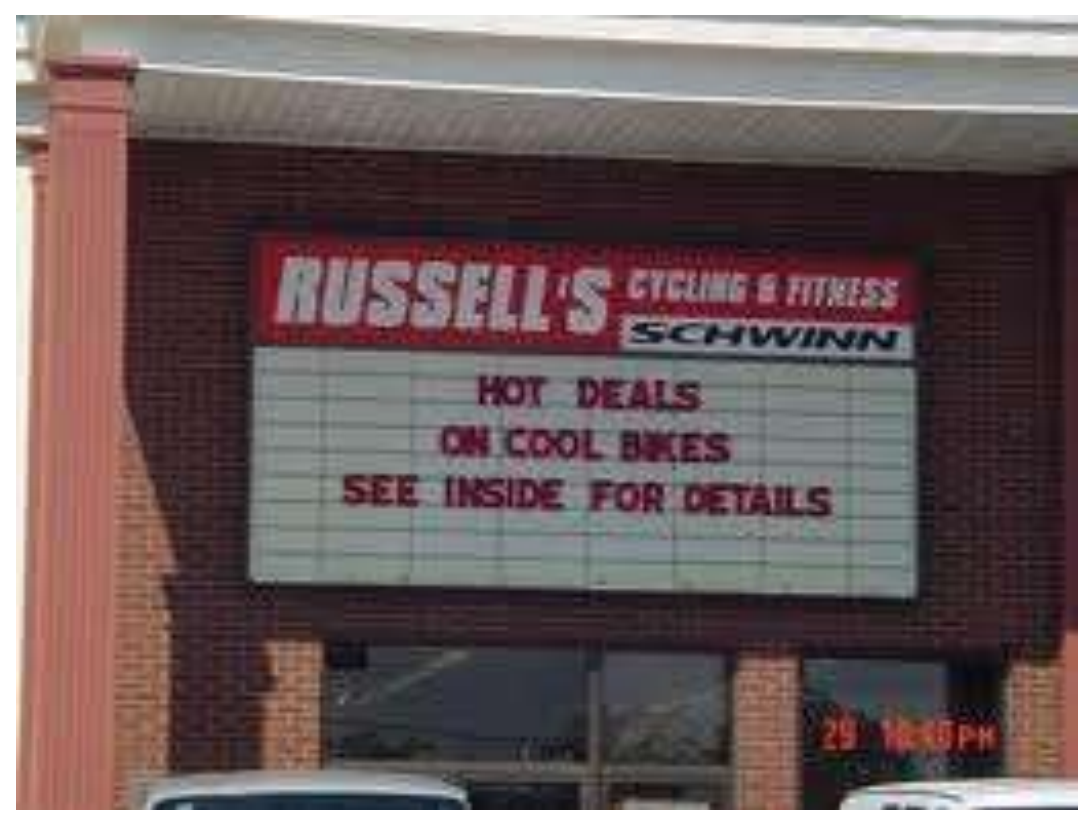

Using The Theatre Marquis

Russell's Cycling and Fitness remains in the same location today, utilizing 8,400 square feet of space. Joe has taken over the basement for storage of bicycles, putting either bikes or exercise equipment (depending on the season) on the display floor. He has built a second floor where he keeps a good selection of bicycles in all price ranges. The movie theatre-sized parking lot is perfect for Russell's Cycling and Fitness as it allows customers to test drive bikes without fear of cars. Joe and Cheryl's offices are in the old projection room of the theatre where they can look out into the showroom (though both of them are on the floor helping customers most of the time).

\section{PROMOTIONAL STRATEGY}

Ever since Joe Russell started Russell's Cycling and Fitness, he has been the face and voice of his advertising. With a friendly, 'Hi, this is Joe Russell from Russell's Cycling and Fitness', the entrepreneur (thanks to coaching from the aforementioned Mary Oakley) has built a reputation for upbeat, fast-paced friendly advertising. Russell has appeared in his own television commercials and voiced his own radio commercials. While some business owners who do their own commercials are less than adequate (and often the butt of jokes) in their presentation, Russell has worked hard to project his sincerity and positive image in his well received advertising.

For many years, Joe Russell has done 'live' radio commercials on a highly rated news talk radio station. Despite the fact that the station no longer allows new 'live' phone-in radio commercials, Russell is 'grandfathered 
in' as the station has agreed to allow him to continue these ads as long as he continues advertising on that station. This is a competitive advantage he enjoys over other bike dealers. In addition, he advertises on three religious radio stations and a light rock radio station on a regular basis. Russell targets the demographics of adults 25-54.

Over the years, Russell's Cycling and Fitness has been inconsistent when it comes to advertising on television. Some years the Russells will dedicate several thousands of dollars on both local and cable TV promoting exercise equipment to the more targeted market of women ages 25-54. Results have been mixed, as Russell's budget has not been large enough to build a lot of frequency with the target market.

Some advertising advisors have pointed out that the news talk station tends to target much older than the 25-54 year-old group, suggesting that Joe's live call-in commercials are not reaching his target market customers. In addition, by not spending enough on TV advertising to build a good frequency, the amount spent on television might be better spent in a different fashion. Russell agrees that these are points to consider.

Russell's Cycling and Fitness also belongs to a bicycle advertising co-op that prepares mailers for him. He will send out six to eight mailers a year to a list of 5,200 customers. The advertising department of the co-op provides the art and lays out the mailer to his satisfaction. Research of the business' best customers shows that they do not perceive these mailings to be advertising flyers, but rather a newsletter from Joe Russell. Once again, Russell's positive influence on his customers is reflected by this belief.

In addition, twice a month Russell's sends out an email to a list of current customers. The content of the email tends to 'sell' more than the advertising flyer. According to Russell, the email is opened by $10 \%$ of the people it is mailed to. At this time, that is the extent of his digital media, other than maintaining a Facebook page and a fairly informative detailed website at www.russellscycling.com.

Russell's Cycling and Fitness tends to follow the advertising adage of "go fishing when the fish are biting." In other words, he only advertises in the months when there is plenty of opportunity for sales. April and May are good months to advertise, as well as November. A month such as August, when families are focusing on back to school purchases, tends to be when he spends very little on advertising.

Russell's advertising budget has historically been in the 7 to $10 \%$ range of his annual gross sales. This concerns Joe and Cheryl as they've discovered most bicycle shops spend no more than $2 \%$ of their gross sales on advertising in a given year. "Are we spending too much on advertising?" is a question Russell struggles with, as well as "Are we spending it in the right places?"

Russell's Cycling and Fitness used to be a regular newspaper advertiser in the two local weekly newspapers, as well as occasional ads in the Peoria daily - the Journal Star. However, he has dropped the newspapers from his budget, as well as his Yellow Pages advertising.

\section{MARKETING STRATEGIES}

The bike shop has also grown because of the many internal marketing strategies the Russells have chosen to undertake. For instance, with the purchase of a new bicycle, the purchaser receives free maintenance for an entire year after the purchase. In addition, a buyer of a new bicycle at Russell's will always be able to trade that bicycle in on a new bike when the time comes. Needless to say, this is a very good strategy for the store as families take advantage of the trade-in policy as their children grow older and need bigger bicycles.

Because Joe and Cheryl are such enthusiastic bike riders themselves, they also run a bike club that twice weekly takes bike rides during the months conducive to bike riding. Though this draws a number of more serious enthusiasts, the owner makes a point of encouraging the casual rider to join them on these rides. "My only requirement is that everyone wears a helmet", says Joe. "We'll wait for the slower ones and make sure everyone has an enjoyable time." In truth, Russell more than just waits for the slower ones. He generally slows down and rides with the slowest rider so he or she won't be all alone. Joe is often joined by wife, children, and other family members. 
For many years, every July - shortly after the fourth - Russell's Cycling and Fitness has held its annual parking lot sale. For many years, this means that July has the highest sales volume of any month of the year. However, expenses have always been high as Joe enlists family members to wait on customers, cook brats, dip ice cream, and serve soft drinks. In addition, Joe provides entertainment of some well-known movie or television character. One parking lot sale featured an actor dressed as Captain Jack Sparrow. The parking lot is filled with over 200 bicycles and prices are lowered to help move merchandise that might not be selling. Historically, the crowds for the parking lot sale have been overwhelming.

However, in 2012 Joe and Cheryl decided not to hold the annual parking lot sale, but instead celebrate their $35^{\text {th }}$ year of being in business with an end-of-June celebration that was not nearly as expensive to run as previous years' parking lot sales. As a result, sales were off $20 \%$ from the previous July's (as expected), but the couple felt the business was as profitable as it was during the years of the sidewalk sale. "We've done the parking lot sale for so many years that maybe we need to bring it back in the future", is a question that Joe asks himself, aware that many customers might have been disappointed that it wasn't held in 2012.

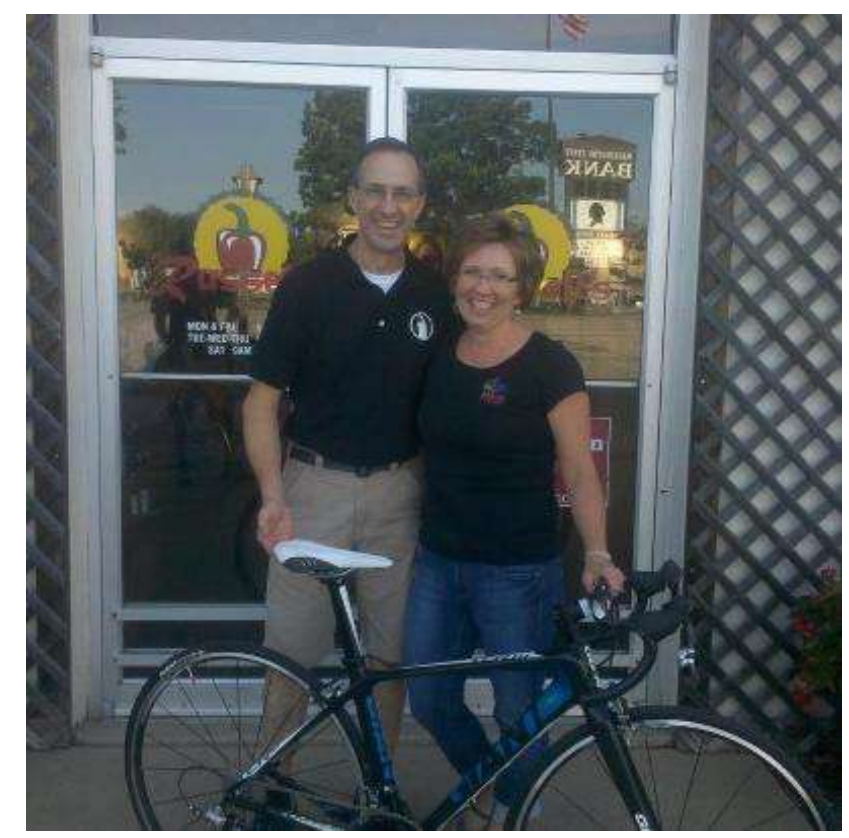

Joe and Cheryl Russell: Partners Since High School

In addition, as would be expected, Joe and Cheryl Russell donate dozens of bicycles to local charities for giving away. Many of Russell's bikes are door prizes at Illinois Valley Striders races and other organizations' events. They also donate bikes to local social agencies to give to families who can't afford bicycles. At Christmastime, Joe and Cheryl ask for donations from friends and customers to help defray the costs of giving. As most people feel the Russells go out of their way to help them, they help the Russells succeed in their efforts to help the community.

Joe often will go to local schools to give free presentations on bicycle safety to young bike riders. Joe's involvement in the community is among the reasons he was selected as the 'Washingtonian of the Year' by the Washington Chamber of Commerce in 2003. On a nationwide basis, the Russells' efforts and resulting success has not gone unnoticed. The store has been recognized as one of the top one hundred bicycle dealers in the country by Bicycle Retailer and Industry News in 2007, 2009, 2010, 2011, and 2012. 


\section{THE BUDGET}

The advertising budget for 2012 (see Table 1) shows the first attempt that the Russells have made to lower their expenditures on advertising and promotion. This 2012 budget represents an expenditure (projected) closer to $5 \%$ of gross sales, which is a decrease from an almost $8 \%$ of gross sales expenditure in 2011.

Table 1: 2012 Advertising

\begin{tabular}{|l|l|l|l|}
\hline \multicolumn{1}{|c|}{ Medium } & \multicolumn{1}{|c|}{ Media } & \multicolumn{1}{c|}{ Months } & \\
\hline & & & \\
\hline Radio & WMBD & January-December & $\$ 10,530.00$ \\
\hline & Talk & & \\
\hline Radio & WVEL & January-December & $\$ 2,400.00$ \\
\hline & WPEO & & $\$ 2,400.00$ \\
\hline & WCIC & & $\$ 2,400.00$ \\
\hline Radio & Religious & & \\
\hline & WSWT & March-June & $\$ 12,000.00$ \\
\hline Internet & Lite Rock & & \\
\hline Bike Connection & Website & January-December & $3,600.00$ \\
\hline Bike Connection & Membership & January-December & $\$ 2,400.00$ \\
\hline & Direct Mail & Feb, March, April & $\$ 27,000.00$ \\
\hline Internet & & June, July, Nov & \\
\hline TV & E Blasts & January-December & $\$$ \\
\hline & Cable & January-February & $\$ 6,600.00$ \\
\hline
\end{tabular}

Obviously, the budget does not show the expenses of maintaining the bike club and the group bike rides, as well as personnel expenditure for same, nor does it reflect the labor involved in creating the minimal amount of social media that the company does.

\section{MEASURING KEY INDICATORS}

Joe measures a number of statistics to help monitor those factors he has control over and those he has no control over. For starters, Joe is able to keep track of how many times someone enters or leaves his business. He calls them 'door bell rings'. In addition, Joe keeps track of the number of sales tickets written each day. He can then come up with a statistic of how many door bell rings it takes for each sales ticket written. He compares both statistics to the same day the previous year. At the same time, Joe takes the total days sales and divides it by the number of tickets written on that day to get an average expenditure per sale.

In his better months, he has tracked that it only takes three door bell rings for every ticket written. In a slow month, the number falls to perhaps one in six. Of course, during the slower months, there are fewer customers coming through the door. Another factor affecting door bell rings is the weather and, not surprisingly, the 2012 Olympics helped increase the store's traffic. The excitement of watching biking in the Olympics generated a lot of interest. In addition, the unusually warm, dry summer actually helped increase business as customers were looking for a fitness workout to help them keep cool.

Joe also measures the trend of the size of the average ticket. He has noticed, as Caterpillar hands out annual bonuses to its employees, the size of the average ticket increases as many employees decide to use some of the bonus money to upgrade their ride.

Joe also uses the information regarding number of bell rings per ticket and average size order to train his sales staff. He works with them on a daily basis to teach them techniques to increase the average order. These are not hard sell tactics; salespeople are simply taught that it's a matter of reminding the customer of extras they may wish to purchase or the suggestion of maintenance on their current bicycle. 
What to do with these statistics and how to turn them into higher sales and greater profit continues to be puzzling to Joe and Cheryl. "If nothing else, we have to believe that if we can increase the average sale, we're going to be more profitable", says Joe. "We've put a lot of effort into working with each one of our salespeople specifically on how to ask the right questions with each and every customer."

A question Joe ponders often is, "If there was a way that we could see more of a correlation between door bell rings and the amount of money we spend on advertising, we could do something to improve it. However, now it appears that the money we spend on advertising has less effect on the business than does weather or the season of the year."

\section{SALES}

Despite the United States and most of the world still enduring a sluggish economy, new competitors in the bicycle and health equipment business, and plenty of exercise-related alternatives to bike riding, Joe continues to be optimistic about the growth of his business. However, he shakes his head and admits his frustration over the fact that his sales have been 'flat' over the past five years.

He points to the interesting fact that, despite no growth, the lack of sales has forced him to pay more attention to "balance sheet" issues. "I pay a lot more attention to my profit margins and my inventory issues than I ever have before", he says. "It's ironic in that if sales had been growing at a fast clip, I wouldn't have been paying attention to my expenses and profit margins as closely; so perhaps the slow economy has been a good thing! It's made me a better manager."

\section{THE FUTURE}

Not unlike a lot of entrepreneurial-based businesses, Russell's Cycling and Fitness is based upon the hard work of its owners, Joe and Cheryl Russell. The couple realizes that they don't want to work forever. The key to the future is how they can turn Russell's Cycling and Fitness into a business that runs itself, not requiring the owners to be there twelve hours a day six days a week.

Both sons are hard workers in the business and have been for a number of years; yet both have separate interests and desires and may not want to become a part of the family business.

With a number of long-term employees working for them, perhaps they are the answer to 'keeping the business alive'. And similar to a lot of entrepreneurial businesses, Joe Russell realizes he needs to get his own ego out of the way if he expects to delegate the day-to-day management of the business to his employees.

"I still want to be involved; there are a lot of areas - advertising and marketing being the major area - where I don't want to loosen control over just yet." After making that comment, Joe's smart phone buzzed and he found he had a coupon sent to him by a local pizza restaurant.

Is this something we should be sending to our customers?, Joe wonders to himself, still marveling over the changes in the advertising and marketing areas of Russell's Cycling and Fitness since the day he worked on his first bicycle in the family garage.

He put his phone back in his pocket and asked Cheryl if she wanted to go for a bike ride and lunch. "I have a coupon!", he told her.

\section{AUTHOR INFORMATION}

Henry Balfanz is a second-year Marketing Instructor at Northern Michigan University. Prior to joining the ranks of academia, Balfanz was involved in the broadcast, print and advertising industries. He managed radio stations in Peoria and Champaign, Illinois, Great Falls, Montana, and Davenport, Iowa. He was also a vice president with an advertising agency in Peoria. He also spent six years as a publisher of a group of nine weekly newspapers. Balfanz 
holds a Bachelor of Science in Broadcast Management from Southern Illinois University and an MBA from Bradley University.

Gary J. Brunswick holds a Ph.D. in Business Administration from Arizona State University, and currently hold the rank of Professor of Marketing at Northern Michigan University. His research interests include marketing strategy, services marketing and e-commerce. His research has been published in range of journals including, Journal of the Academy of Marketing Science, Journal of Consumer Behaviour, The Marketing Management Journal, The Journal of Professional Services Marketing, The International Journal of Case Studies and Research, The Journal of the International Academy of Case Studies, The Academy of Educational Leadership Journal and The Academy of Marketing Studies Journal. E-mail: gbrunswi@nmu.edu (Corresponding author) 


\section{STUDY NOTES FOR RUSSELLS CYCLING AND FITNESS}

1. Do you agree with Russell's Cycling and Fitness's choice of advertising media? Is Russell's hitting its target market in the proper fashion?

2. If other bike dealers do little or no advertising, should Russell's attempt the same strategy? What are the pros and cons of this strategy?

3. Are there other areas complementary to bicycles and exercise equipment that the Russells should consider adding to the store?

4. How can the Russells study the relationship among advertising expenditures, door bell rings, average expenditures by customers, in order to turn the information into higher sales?

5. How can the Russells better utilize social media in their marketing?

6. Should the lack of sales growth over the past five years be a major concern to Russell's Cycling and Fitness? Why or why not? 
NOTES 